\title{
Kontribusi Minat Baca dan Bimbingan Belajar Orangtua Terhadap Prestasi Belajar Siswa Sekolah Dasar
}

\author{
Mulyati \\ Universitas Negeri Sebelas Maret
}

\begin{abstract}
This research is intended to determine whether or not there is a correlation between reading interest and parents guidance in leaming and the studenis learning achievement, either separately or simultaneously. The correlational research was conducted from April to August 2000. The population was students of the State Elementary Schools (SDN) in the District of Laweyan Surakarta in the 1999/2000 academic year. The sample was 30 students taken using stratified random sampling technique. A questionaire is used to measure reading interest and parents' guidance in learning. The data of the students' achievements were collected by using documentation. Data were anaysed using correlation and regression. The result shows that: (1) there is a positive corrolation between reading interest and students' achievement $(r=93)$ and a liner regression equation of $Y=1.080+.072 X_{i}$. (2) there is a positive correlation between parents' guidance and students achievement is $=94$ ) and a linear regression of $Y=2.121+.061 X_{z i}$ (3) there is a simultaneous correlation between reading interest, parents guidance in lea ming and the students' achievement $(R=92)$ and a linear regression of $Y=1.345+.036 X_{1}+.033 X_{2}$
\end{abstract}

Key words: learning/school achievement, reading interest, parent guidance.

\section{Pendahuluan}

$\mathrm{K}$ etika anak masuk ke bangku pendidikan (formal) ia membiai kegiatan belajar. Hal itu bukan berarti sebelumnya ia belum melakukan aktivitas belajar. Di bangku Taman Kanak-Kanak, bahkan jauh sebelum itu ia -di lingkungan rumah maupun di lingkungan masyarakat- sudah belajar. Namun demikian kegiatan belajar yang ia lakukan dibangku sekolah formal dan di rumah atau masyarakat berbeda. Kegiatan belajar yang dilakuan d sekolah dilakukan secara berencana dan sistematis. Hal itu terlihat pada adanya kurikulum, tujuan yang jelas, materi yang

sudah dipersiapkan, guru atau pengajar, jadwal kegiatan, dan kegiatan evaluasi. Sementara iku, kegiatan belajar di lingkungan keluarga dan juga di masyarakat tidak demikian halnya.

Pencapaian tujuan belajar sebagaimana dirnaksudkan di atas ditandal dengan adanya perubahan pada diri pembelajar, baik dalam behaviorial changes, aktual, maupun potensial. Dengan belajar akan dihasilkan kecakapan baru. Setelah belajar orang atau anak memiliki keterampilan, pengetahuan, sikap, dan nilai. Pengetahuan, sikap, dan keterampilan iku tercermin pada prestasi yang 
diperoleh siswa. Prestasi inilah yang dijadikan ukuran keberhasilan kegialan belajar anak.

Pencapaian prestasi itu dipengaruhi oteh beberapa faktor, baik faktor dari dalam maupun dari luar individu. Faktor-faktor dari dalam individu itu adalah minat, motivasi, kedisiplinan, intelegensi, dan sebagainya. Sementara itu, faktor-faktor dari luar individu adalah fasilitas belajar, lingkungan atau situasi rumah, bimbingan orang tua, dan sebagainya.

Dari sejumlah faktor internal yang ada, faktor minat -khususnya minat baca-kiranya merupakan faktor penting yang perlu diperhatikan. Hal itu terutama berkaitan dengan kenyataan bahwa sebagian kegiatan belajar dilakukan dengan membaca. Sumber pengetahuan terbesar diperoleh dari bahan bacaan. Dengan dimilikinya minat baca yang tinggi anak akan banyak melakukan aktivitas membaca dan disertal intensitas baca yang tinggi. Frekuensi membaca dan intensitas membaca yang tinggi akan mempengaruhi kemampuan membaca anak dan dampak ikutannya adalah pengetahuan yang diperolehnya makin banyak pula. Permasalahannya kemudian adalah seberapa besar kontribusi minat baca itu terhadap prestasi belajar? Sementara itu, faktor internal yang kiranya perlu mendapat perhatian adalah bimbingan belajar orang tua. Bimbingan belajar orang tua memegang peranan penting untuk meningkatkan prestasi belajar anak karena anak-anak usia sekolah dasar masih sangat membutuhkan arahan dan nasihat dalam melakukan aktivitas belajarnya. Sumbangan kedua faktor d alas terhadap prestasi belajar anak perlu diketahui. Hal inilah terutama yang mendorong dilakukannya penelitian ini.

Berdasarkan uralan di atas, permasalahan yang ingin dijawab lewat penelitian ini adalah sebagai berikut: (1) Apakah terdapat hubungan antara minat baca dan prestasi belajar? Apabila ada, bagaimana bentuk hubungan dan seberapa kuat hubungan tersebut? (2) Apakah lerdapat hubungan antara bimbingan belajar orang tua dan prestasi belajar? Apabila ada, bagaimana bentuk hubungan dan seberapa kuat hu-bungan tersebut? (3)Apakahterdapat hubungan antara minat baca dan bimbingan belajar orang tua secara bersama-sama dengan prestasi belajar? Apabila ada, bagaimana bentuk hubungan dan seberapa kuat hubungan tersebut?

\section{Tinjauan Pustaka}

Untuk memperjelas konsep yang berkaitan dengan variabel-variabel di atas, berikut ini disajikan deskripsi singkat tentang ketiganya, yaitu berturut-turut prestasi belajar, minat baca, dan bimbingan belajar orang tua. Terdapat banyak sekali definisi belajar. Dengan mengutip pendapat Cronbach, Spears, dan McGeoch, Sumadi (1987) menyimpulkan bahwa (l) belajar itu membawa perubahan (dalam arti behaviorial changes, aktual, maupun potensial); (2) perubahan itu pada pokoknya adalah diperolehnya kecakapan baru; dan (3) perubahan itu terjadi karena usaha.

Pengertian belajar di atas senada dengan pendapat Winkel dan Gagne. Winkel (1983: 13) menjelaskan bahwa ciri khas gejala belajar bilamana telah terjadi suatu perubahan pada orang yang belajar. Sementara itu menurut Gagne (1977), belajar adalah seperangkat proses kognitif yang mengubah sifat stimulasi lingkungan melalui pengolahan informasi menjadi kapabilitas baru.

Betajar terdiri atas tiga komponen penting, yaitu kondisi internal, kondisi eksternal, dan hasil belajar (Dimyati dan Mudjiono, 1994). Lebih lanjut dikatakannya bahwa belajar merupakan proses internal yang kompleks, yang melibatkan seluruh mental, yang meliputi ranah kognitif, afektif, dan psikomotorik.

Senada dengan pendapat di atas, menurut Crow dan Crow (1989), belajar adalah hal memperoleh kebiasaan, pengetahuan, dan sikap. la melahirkan caracara baru untuk melakukan sesuatu dan ia 
mengusahakan individu mengatasi rintangan atau menyesuaikan diri dengan situasi baru.

Perubahan yang terjadi pada diri pelajar yang telah dikemukakan para ahli di atas juga ditegaskan oleh Wolfolk dan Nicolich. Perubahan itu harus disebabkan oleh pengalaman dan interaksi seseorang dengan lingkungannya. Hal itu berarti bahwa pengalaman merupakan aspek penting dalam belajar. (Wolfolk dan Nicolich, 1984).

Berdasarkan berbagai pendapat tentang belajar di atas dapat dikemukakan beberapa unsur penting yang terdapat dalam belajar, yaitu (l) belajar dilakukan untuk memenuhi kepentingan atau mencapai tujuan tertentu; (2) belajar menyebabkan terjadinya perubahan; (3) perubahan dalam belajar dapat bersifat positif dan sebaliknya dapat bersifat negatif; (4) perubahan itu terjadi dalam aspek kognitif, afektif, maupun psikomotorik; (5) terjadinya perubahan itu karena ada usaha; (6) belajar dapat terjadi di mana saja dan kapan saja; dan (7) dalam proses belajar diperlukan stimulasi atau perangsangan.

Kegiatan belajar yang dilakukan siswa tentu akan membuahkan hasil, yang sering disebut dengan prestasi belajar. Sebagaimana dijelaskan dalam Kam us Besar Bahasa Indonesia (1989), kata prestasi berarti hasil yang telah dicapai.

Menurut Bloom, hasil belajar dapat dibedakan atas tiga kategori atau yang biasa dikenal dengan ranah, yaiku ranah kogrilif, afektif, dan psikomotorik (Burhan, 1987). Sementara itu menurut Gagne (1989) hasil belajar atau kapabilitas hasil belajar meliputi keterampilan intelektual, informasi verbal, siasat kognitif, keterampilan motoris, dan sikap.

Berdasarkan uraian di atas dapat disimpulkan pengertian prestasi belajar, yaitu keterampilan atau kecakapan yang dimiliki siswa yang diperolehnya setelah melalui proses belajar, yang mencakupi bidang kognitif, afektif, dan psikomotorik. Adapun prestasi belajar yang dimaksudkan dalam penelitian ini adalah nilai rata-rata yang diperoleh siswa yang tercantum dalam rapor.
Variabel kedua adalah minat baca. Minat menurut Doyles Fryer (dalam Wayan dan Sumartana, 1983), adalah gejala psikis yang berkaitan dengan objek atau aktivitas yang menstimulasi perasaan senang pada individu. Minat berkaitan erat dengan kebutuhan. Minat yang timbul dari kebutuhan anak merupakan faktor pendorong bagi anak dalam melaksanakan usahanya. Pendapat Fryer didukung oleh pendapat Jersild dan Tasch (lihat pula Wayan dan Sumartana, 1983). Mereka menekankan bahwa minat menyangkut aktivitas-aktivitas yang dipilih secara bebas oleh individu.

Penjelasan kedua ahli di atas sejalan dengan pondapat Witherington (1981), yang menyatakan bahwa minat ialah kesadaran seseorang bahwa suatu objek, seseorang, suatu soal atau suatu situasi mengandung sangkut paut dengan dirinya.

Minat sebagai dorongan yang menunjukkan perhatian individu terhadap objek yang menarik atau menyenangkan. Jika individu memperhatikan suatu objek yang menyenangkan, maka ia cenderung akan berusaha lebih aktif dengan objek tersebut (Skinner, 1977). Hal demikian juga ditegaskan oleh Crowdan Crow (1989) yang menyatakan bahwa minat merupakan kekuatan yang mendorong individu dalam memberi perhatian terhadap suatu kegiatan.

Hubungan yang erat antara kesenangan dan minat dikemukakan pula oleh Hurlock; namun, diingatkannya bahwa antara keduanya tidak sama. Kesenangan merupakan minat yang sementara. Kesenangan berbeda dengan minat bukan dalam kualitas, melainkan dalan ketetapan (persistence) (Hurlock, 1993).

Rumusan pengertian minat yang lebih operasional dikemukakan oleh Rats, Harmin, dan Simon (1996). Menurut mereka, minat adalah sesuatu yang dapat membangkitkan gairah seseorang dan menyebabkan orang itu menggunakan waktu, uang, serta energi untuk kesukaannya terhadap objek tersebut.

Berdasarkan uraian di atas, dapat dikemukakan sejumlah hal pokok yang 
terdapat dalam minat: (1) adanya perasaan senang dalam diri yang memberikan perhatian pada objek tertentu, (2) adanya ketertarikan terhadap objek tertentu, (3) adanya aktivitas atas objek yang dipih, (4) adanya kecenderungan berusaha lebih aktif, (5) objek atau aktivitas tersebut dipandang fungsional dalam kehidupan, dan (6) cenderung bersifat mengarahkan dan mempengaruhi tingkah laku individu.

Dan hal-hal pokok di atas dapat disimpulkan pengertian minat baca, yaitu gejala psikis yang berkaiatan dengan aktivitas membaca yang menstimulasi perasaan senang dan mengarahkan siswa pada aktivitas membaca. Adapun indikatorindikator yang digunakan untuk melihat minat baca siswa adalah (1) perhatian siswa terhadap membaca, (2) penggunaan waktu dalam atau untuk membaca, (3) pemakaian uang untuk sesuatu yang berhubungan dengan kegiatan membaca, dan (4) penggunaan energi untuk kegiatan membaca.

Keberhasilan seseorang, termasuk siswa, dalam melakukan kegiatan membaca banyak ditentukan minat bacanya. Tingkat motivasi yang ditunjukkan para pembaca terhadap buku-buku bergantung pada sifat alami dan kuailtas minat, sumber minat, dan variasi dalam memfokuskan minat.

Variabel ketiga adalah bimbingan belajar orang tua. Bimbingan, sebagai suatu istilah, diberi pengertian yang berbeda-beda oleh para ahli. Menurut Djumhurdan Surya (1975), bimbingan adalah suatu proses pemberian bantuan secara terus-menerus dan sistematis kepada individu dalam memecahkan masalah-masalah yang dihadapinya agar tercapai kemampuan untuk dapat memahami dirinya (self understanding), kemampuan untuk menerima dirinya (self acceptance), kemampuan untuk mengarahkan dirinya (self direction), dan kemampuan untuk merealisasikan dirinya (self realization) sesuai dengan potensi atau kemampuannya dalam mencapai penyesuaian diri dengan lingkungan baik keluarga, sekolah maupun masyarakat.
Senada dengan pendapat di atas, Winkel (1978) menjelaskan bahwa bimbingan berarti pemberian bantuan kepada seseorang atau sekelompok orang dalam membuat pilihanpilihan secara bijaksana dan dalam mengadakan penyesuaian diri terhadap tuntutan-tuntutan hidup. Dengan bantuan (bersifat psikis) itu seseorang akhirnya dapat mengatasi sendiri permasalahan yang sedang dihadapinya.

Bimo Walgito (1982) mengemukakan pendapat yang sejalan dengan pendapat di alas. Menurutnya, bimbingan adalah bantuan atau pertolongan yang diberikan kepada individu atau sekumpulan individu dalam menghindari atau mengatasi kesulitankesulitan di dalam kehidupannya untuk memgembangkan kemampuan-kemampuannya agar individu atau sekumpulan individu itu dapat memecahkan masalahnya sendiri dan dapat mengadakan penyesuaian dengan baik untuk mencapai kesejahteraan hidupnya.

Bimbingan yang dimaksudkan dalam penelitian ini adalah bimbingan belajar. Dengan mengacu pada pengertian belajar yang telah diuraikan di muka dapat dirumuskan pengertian bimbingan belajar, yaitu proses pemberian bantuan secara terusmenerus dan sistematis kepada individu đalam memecahkan masalah-masalah belajar yang dihadapinya sehingga individu tersebut memiliki berbagai kemampuan sesuai dengan potensinya dalam mencapai penyesuaian diri dan tujuan belajar.

Jenis bimbingan belajar itu, menurut Djumhurdan Surya (1975), antara lain adalah (1) mendapatkan cara belajar yang efisien; (2) menentukan cara mempelajari atau menggunakan buku pelajaran; (3) membuat tugas-tugas sekolah, mempersiapkan diri untuk ulangan atau ujian; (4) menghadapi kesulitan-kesulitan dalam mata pelajaran tertentu: (5) menentukan pembagian waktu dan perencanaan belajar; dan (7) memilih pelajaran tambahan.

Bimbingan belajar kepada anak dapat dilakukan oleh guru maupun orang tua. 
Bimbingan yang diberikan guru terutama ketika anak dalam lingkungan sekolah; sementara itu, bimbingan yang diberikan oleh orang tua mencakupi wilayah yang lebih luas, baik yang berkaiatan dengan keberadaan anak di sekolah dan telebih lagi ketika anak d lingkungan rumah atau keluarga dan lingkungan sosial masyarakat.

Sumbangan orang tua teriadap kegiatan ada sangat besar. Sikap dan perilaku orang tua terhadap anak akan menentukan gaya orang tua dalam mendidik dan memberikan bimbingan belajar kepada anak tersebut. Sebagian orang tua bersikap kaku dan karenanya tidak dapat mengadakan pendekatan kepada anak; sebaliknya, ada orang tua yang sangat menaruh perhatian kepada anak sehingga mereka dapat berkomunikasi dengan baik. Selain itu, ada juga orang tua yang bersikap masa bodoh terhadap anaknya. Orang tua demikian beranggapan bahwa anak dapat memahami dírinya sendiri dan karena itu bimbingan orang tua tidak diperlukan. Gaya orang tua dalam mendidik anak, menurut Dimyati Mahmud (1989), dapat dibedakan atas gaya autoritatif, gaya autoritarian, dan gaya permisif.

Berdasarkan uraian di atas dapat dirumuskan konstruk bimbingan belajar orang tua, yaitu proses pemberian bantuan secara tens-menerus dan sistematis yang dilakukan orang tua kepada anaknya guna memecahkan masalah-masalah belajar yang dihadapinya sehingga anak tersebut memiliki berbagai kemampuan sesuai dengan potensinya dalam mencapai penyesuaian díri dan tujuan belajar. Adapun indikator bimbingan belajar itu meliputi: (1) memahami kesulitan belajar anak, baik kesulitan belajar yang berasal dari anak (internal) maupun kesulitan belajar yang berasal dari luar anak (eksternal), (2) membantu mengatasi berbagai kesulitan belajar yang dialami anak, (3) memotivasi anak untuk belajar, dan (4) memahami kebutuhan anak untuk belajar.

Bertitik tolak pada deskripsi teoretis di atas dapat disusun kerangka berpkir berikut in. Minat menyangkut aktivitas-aktivitas yang dipilih secara bebas oleh individu. Minat berkaitan erat dengan kebutuhan. Dorongan kebutuhan itulah yang menstimulasi orang untuk melakukan sesuatu yang diminati. Ketika anak menyadari bahwa membaca merupakan suatu yang bernilai dalam kehidupannya dan sekaligus merupakan suatu yang dibutuhkan, maka ia akan menaruh perfiatian yang besar pada kegiatan membaca. Anak itu akan mencurahkan waktu, tenaga, dan pikirannya untuk melakukan kegiatan membaca dengan penuh semangat.

Dengan dimilikinya minat baca, anak akan makin ekstensif dan intensif dalam kegiatan membaca. Ekstensif daiam pengertian ia akan berusaha membaca berbagai bahan baacaan yang dipandang berguna atau mendatangkan manfaat pada dirinya. Sebagai seorang pelajar, ia tidak akan puas jika hanya membaca buku-buku wajb yang ditunjukkan oleh gurunya. la akan berusaha mencari bacaan dari berbagai sumber dan membacanya guna mengetahui dan memahami isi/gagasan yang terdapat di dalamnya. Sementara itu, sifat intensif dapat dilihat dari makin besarnya usaha untuk menyerap informasi sebanyak-banyaknya dari bahan bacaan yang dihadapinya, senantiasa berikhtiar untuk memperbaiki pemahamannya teriadap bacaan, mengatasi hambatanhambatan membaca yang masih dimilikinya, dan lebih dari itu makin bersifat kritis dan responsif terhadap informasi atau gagasan yang diperoleh lewat bacaan.

$\mathrm{Hal}-\mathrm{hal}$ yang telah dikemukakan di atas sangat berguna dan mendukung kegiatan belajar sehingga akan berdampak pada meningkatnya prestasi belajar. Hal itu kiranya dapat dipahami karena sebagaian besar aktivitas belajar dilakukan dengan membaca. Berdasarkan uraian di atas dapat diduga bahwa terdapat hubungan positif antara minat baca dan prestasi belajar. Dengan perkataan lain, dapat diduga makin tinggi minat baca seorang anak akan makin tinggi pula prestasi belajar mereka.

Dalam aktivitas belajar anak sering 
menemui kesulitan. Berbagai kesulitan in harus diatasi agar capaian tujuan belajar secara optimal dapat diwujudkan. Upaya mengatasi berbagai kesulitan itu tidak cukup jika hanya dibebankan kepada anak. Orang tua mempunyai tugas dan tanggung jawab untuk membantu meringankan atau mengatasi permasalahan-permasalahan atau kesulitan-kesulitan belajar yang dia|ami anak. Pentingnya keteribatan orang tua dalam menangani permasalahan belajar anak didasarkan pada sejumlah pertimbangan, yang antara lain (i) anak-anak usia sekolah dasar pada umumnya belum sepenuhnya dapat mandiri dalam kegiatan belajar dan (2) lingkungan keluarga (tempat orang tua dan anak bertempat tinggal dan berinteraksi) merupakan lingkungan yang pertama dan utama bagi anak. Selain itu, waktu terbanyak yang dimiliki siswa (anak) di gunakan di rumah.

Dengan pemberian bimbingan yang sungguh-sungguh orang tua akan dapat memahami berbagai kebutuhan anak (khususnya kebutuhan belajarnya), memahami berbagai permasalahan atau kesulitan belajar yang dihadapinya, memahami faktor-faktor yang menyebabkan munculnya permasalahan tersebut, dan akhirnya orang tua akan mampu memberikan saran-saran, arahan, petunjuk, atau bahkan perintah kepada anak guna mengatasi persoalan yang dihadapinya. Pemecahan terhadap kesulitan belajar yang ada memberikan sumbangan yang besar terhadap tercapainya tujuan belajar. Berdasarkan uraian di alas dapat diduga bahwa terdapat hubungan positif antara bimbingan belajar dan prestasi belajar.

Kedua faktordi atas sama-sama memilki arti pening bagi terwujudnya prestasi belajar anak. Salah satu faktor d antara kedua faktor itu tidak bisa dipandang remeh; dan sebaliknya, hanya menekankan pada faktor tertentu saja. Berdasarkan hal itu maka dapa: diduga terdapat hubungan positif minat baca dan bimbingan belajar orang tua dengan preslasi belajar.

\section{Metode Penelitian}

Sesuai dengan tujuan penelitian yang telah dikemukakan, metode penelitian yang digunakan adalah metode penelitian deskriptif korelasional. Penelitian deskrlptif adalah penelitian yang bertujuan untuk mengemukakan fenomena tertentu pada masa sekarang. Sementara itu, penelitian korelasional, menurut Sumadi (1983), adalah penelitian yang bertujuan mendeteksi seberapa jauh variasi-variasi pada suatu faktor berkaitan dengan variasi-variasi pada satu atau lebih faktor lain berdasarkan pada koefisien korelasi.

Populasi penelitian ini ialah siswa Kelas $\checkmark$ Sekolah Dasar Negeri di Kecamatan Laweyan Kotamadia Surakarta Tahun pelajaran 1999/2000. Dari jumlah siswa yang ada diambil sebanyak 30 orang dengan menggunakan stratified random sampling.

Seperti telah dikemukakan, variabel penelitian ini terdiri atas dua variabel bebas, yang meliputi minat baca $\left(x_{1}\right)$ dan bimbingan belajar orang tua $\left(X_{y}\right)$ dan sat variabel terikat, yaitu prestasi belajar $(Y)$. Data variabel minat baca dan bimbingan belajar orang tua diperoleh dengan teknik angket; sedangkan data variabel prestasi belajar diperaleh dengan teknik dokumentasi. Insirumen penelitian yang berupa angket tersebut sebelum digunakan diujicobakan untuk diketahui validitas dan reliabiliasnya.

Data yang telah terkumpul dianalisis dengan teknik statistik regresi dan korejasi (Sudjana, 1992). Sebelum analisisdilakukan, diadakan pemeriksaan data yang mencakupi (1) uji normalitas distribusi populasi, (2) uji homogenitas varians, dan (3) uj linearitas. Uji normalias dilakukan dengan menggunakan teknik Lilliefors, uji homogenitas dilakukan dengan menggunakan teknik Bartlett, dan uj linearitas dilakukan dengan menggunakan teknik ANAVA. 


\section{Has il}

Semua persyaratan analisis yang meliputi normalitas data, homogenitas varian sebagaimana disebutkan di atas terpenuh. Dengan demikian simpulan-simpulan yang dihasilkan dari analisis data dapat digeneralsasikan pada populasi penelitian.

Hasil penelitian secara deskriptif menunjukkan bahwa skor atau nilai rata-rata dari minat baca, bimbingan belajar orang fua, dan prestasi belajar siswa masing-masing adalah 94,$53 ; 93,33$; dan 7,87 . Sementara ifu, simpangan baku dari ketiga variabel itu masing-masing adalah 6,$78 ; 7,99$; dan 0,52 . Dari data tersebut terlihat bahwa rata-rata prestasi siswa tergolong tinggi. Implikasinya, prestasi siswa tersebut perlu dipertahankan dan bahkan ditingkatkan.

Dari angka-angka simpangan baku di atasd dapat dinyatakan bahwa minat baca dan bimbingan belajar orang, dan prestasi belajar siswa cukup heterogen. Hal itu diperkuat oleh lebamya rentangan skor atau nilai dari masing-masing variabel. Skor terendah untuk minat baca sebesar 79 , sedangkan skor tertingginya 108 , yang berałi memiliki rentangan skor sebesar 29. Skor terendah untuk bimbingan belajar orang tua sebesar 77 , sedangkan skor tertingginya 111 , yang berarti memiliki rentangan skor sebesar 34. Sementara itu nilai terendah untuk prestasi belajar siswa sebesar 6,8 , sedangkan nilai tertingginya 8,7 , yang berarti memiliki rentangan nilai sebesar 1,9 . Implikasi penting terhadap temuan itu adalah bahwa dalam pelaksanaan pembelajaran di kelas atau d sekolah guru periu memperhatikan keadaan siswa yang beragam tersebut. Keadaan siswa yang cukup heterogen itu menuntut guru untuk melakukan pendekatan secara individual (selain pendekatan secara klasikal) dalam menangani persoalan-persoalan belajar yang dihadapi oleh para siswa.

Hal penting lain yang perlu dikemukakan berkenaan dengan hasil pengujian secara deskriptif di atas adalah adanya temuan bahwa minat baca siswa memiliki skor yang tidak jauh berbeda dengan skor bimbingan prestasi belajar orang tua. Hal itu terlihat bukan saja pada skor rata-ratanya, tetapi juga pada rentangan skomya. Fenomena tersebut antara lain dapat diduga karena adanya dorongan belajar dari orang tua sehingga minat baca siswa menjadi baik.

Hasil penelitian inferensial menunjukkan bahwa (1) terdapat hubungan positif antara minat baca dan prestasi belajar siswa ( $r=$ 0,93) melalui persamaan regresi linear $Y=$ $1,080+0,072 X_{1 ;}$ (2) terdapat hubungan positif antara bimbingan belajar orang tua dan prestasi belajar siswa $(r=0,94)$ melalui persamaan regresi linear $Y=2,121+0,061$ $X_{2}$; dan (3) terdapat hubungan positif antara minat baca dan bimbingan belajar orang tua secara bersama-sama dengan prestasi belajar siswa $(R=0,92)$ melalui persamaan garis regresi linear $Y=1.345+0,036 X_{1}+$ $0,033 X_{2}$.

Berdasarkan hasil di atas terbukti bahwa baik secara sendiri-sendiri maupun bersamasama minat baca dan bimbingan belajar orang tua memiliki hubungan positif yang linear dengan prestasi belajar siswa. Min at baca dan bimbingan belajar orang tua berjalan seiring dengan prestasi belajar siswa. Dengan perkataan lain, meningkatnya minat baca dan makin intensifnya bimbingan belajar orang tua akan makin tinggi pula prestasi belajar siswa. Berdasarkan temuan itu dapat dinyatakan bahwa prestasi belajar anak dapat ditelusuri, dijelaskan, atau bahkan dapat diramalkan dari minat bacanya dan bimbingan belajar yang diberikan orang tua kepadanya.

Hal yang periu dipertanyakan berkenaan dengan temuan di atas adalah seberapa kuat hubungan antara minat baca dan bimbingan belajar orang tua selaku variabel bebas dengan prestasi belajar siswa sebagai variabel terikat. Persoalan itu dapat dijawab dengan melihat besar sumbangan kedua vaiabel bebas terhadap variabel terikat dan besarnya koefisien arah pada persamaan garis regresi. Dari koefisien-koefisien korelasi yang telah dikemukakan di depan dapat 
ditentukan besar sumbangan masing-masing atau secara bersama-sama variabel bebas pada variabel terikat. Sumbangan itu adalah (1) minat baca memberi sumbangan $86,49 \%$ pada prestasi belajar siswa; bimbingan belajar orang tua memberikan sumbangan sebesar $88,36 \%$ pada prestasi belajar siswa; dan (3) minat baca dan bimbingan belajar orang tua secara bersama-sama memberikan sumbangan sebesar $84,64 \%$ pada prestasi belajar siswa.

Berdasarkan angka-angka di atas terlihat secara nyata bahwa sumbangan minat baca dan bimbingan belajar orang tua pada prestasi belajar siswa relatif sama. Hal itu menunjukkan bahwa hubungan antara minat baca dan prestasi belajar siswa hampir sama kuatnya dengan hubungan antara bimbingan belajar orang tua dan prestasi belajar siswa. Dengan perkataan lain, keduanya memiliki peranan yang besar bagi terwujudnya prestasi belajar anak. Pentingnya peranan kedua variabel tersebut juga tampak pada koefisien arah regresi yang dimilikinya. Secara sendiri-sendiri koefisien arah regresi minat baca $(0,072)$ dan bimbingan belajar orang tua $(0,061)$ cukup berarti dan demikian pula secara bersama-sama.

Dari temuan yang telah dipaparkan di atas nyata sekali bahwa minat baca dan bimbingan belajar orang tua sama-sama memiliki peranan yang penting bagi pencapalan prestasi belajarsiswa. Hal itu sejalan dengan pendapat Crow dan Crow (1989) yang menyatakan bahwa belajar merupakan suatu proses yang aktifyang perlu dirangsang atau distimulasi dan dibimbing ke arah hasil-hasil dikehendaki.

Temuan penelitian di atas juga sejalan dengan pendapat Sumadi (1987). Menurutnya, faktor-faktor yang mempengaruhi belajar dapat dibedakan atas faktor yang berasal dari diri si anak dan faktor yang berasal dari luar si anak. Faktor minat baca dapat dimasukka ke dalam faktor anak. Sementara bimbingan belajar orang tua dapat dikategorikan sebagai faktor yang berasal dari luar diri anak, khususnya berupa faktor sosial (manusia). Pentingnya faktor internal dan eksternal dalam kegiatan belajar siswa juga dikemukakan oleh Dimyati dan Mudjono (1994). Menurut mereka, faktor internal adalah kegiatan yang dialami dan dihayati oleh siswa; sedangkan faktor eksternal adalah pengajaran yang dilakukan oleh guru dan orang tua.

\section{Pembahasan}

Berdasarkan uraian di atas dapat disimpulkan bahwa minat baca dan bimbingan belajar orangtua $3 / 4$ baik secara sendiri -sendiri maupun secara bersama- memiliki hubungan positif dengan prestasi belajar siswa. Sumbangan yang diberikan minat baca pada prestasi belajar siswa hampir sama dengan sumbangan yang diberikan oleh bimbingan belajar orang tua.

Simpulan itu -dan juga hasil analisis deskriptif- mempunyai sejumlah implikasi penting terhadap upaya meningkatkan prestasi belajar siswa. Pertama, prestasi belajar siswa yang rata-ratanya sudah cukup bagus harus dipertahankan dan bahkan ditingkatkan. Kedua, peningkatan prestasi belajar siswa dapat dilakukan dengan meningkatkan minat baca siswa dan meningkatkan intensitas bimbingan belajar yang dilakukan para orang tua anak. Peningkatan minat baca itu tentu menjadi tanggung jawab bersama guru, sekolah, orang tua, dan masyarakat. Ketiga, agar siswa dapat mencapai prestasi optimal, maka selain peningkatan kedua faktor di atas, perlu dilakukan upaya-upaya lainnya; misalnya perbaikan mutu pembelajaran yang dilakukan guru.

Berdasarkan simpulan penelitian di atas dapat dikemukakan saran berikut inl. Pertama, minat baca siswa perlu terus ditingkatkan, yang antara lain dengan cara memperbanyak koleksi buku perpustakaan sekolah dan pemberian tugas membaca oleh guru. Kedua, bimbingan belajar yang diberikan oleh orang tua di rumah sebaiknya dilakukan dengan mendasarkan masukan 
dari guru. Hal itu diperlukan agar bimbingan itu sejalan dengan yang diberikan guru.

\section{Daftar Pustaka}

Anton M. Moeliono. 1989. Kamus besar Bahasa Indonesia. Jakarta: Balai Pustaka.

Bimo Walgito. 1982. Bimbingan dan Konseling of Perguruan Tinggi. Yogyakarta: Fak. Psikologi UGM.

Burhan Nurgiyantoro. 1987. Penilaian dalam Pengajaran Bahasa dan Sastra. Yogyakarta: BPFE

Crow, L dan A Crow. 1989. Psychologi Pendidikan. Terjemahan Abd. Rachman Abror. Yogyakarta: Nur Cahaya.

Dimyati dan Mudjiono. 1994. Belajar dan Pembelajaran. Jakarta: Ditjen Dikti Depdikbud.

Dimyati Mahmud. 1989. Psikologi Pendidikan. Jakarta: Depdikbud.

Gagne, Robert M. 1977. Essensials of Leaming for instruction. New York: Holt, Rinehart and Winston.

1989. Kondisi Belajar dan Teori Pembelajaran. Terjemahan Munandir. Jakarta: Ditjen Dikti Depdikbud.

Hurlock, Elizabeth B. 1993. Perkernbangan Anak, Edisi Keenam, terjemahan Mitasari Tjandrasa. Jakarta: Erlangga.
I. Djumhur dan Moh. Surya. 1975. Bimbingan dan Penyuluhan of Sekolah. Bandung: CVIImu.

Rats, L.E.; Meril Harimin; and Sidney B. Simon. 1996. Value and Teaching; Working with Value in the Classroom. Columbus, Dhio: Charies E. Meril Publishing $\mathrm{Co}$.

Skinner, Charles E. 1977. Educational Psychology. New Delhi: Prentice-Hall of India Private Limited.

Sudjana. 1992. Teknik Analisis regresi dan Korelasi: Bagi Para Peneliti. Bandung: Tarsito.

Sumadi Suryabrata. 1987. Psikologi Pendidikan. Jakarta: Rajawali.

Wayan Nurkancana dan P.P.N. Sumartana. 1983. Evaluasi Pendidikan. Surabaya: Usaha Nasional.

Winkel, W.S. 1978. Bimbingan dan Penyuluhan of Sekolah Menengah. Jakarta: Gramedia.

1983. Psikologi Pendidikan dan Evaluasi Belajar. Jakarta: PT Gramedia.

Witherington, H.C. 1981. Educational Psychology, terjemahan M. Buchory. Bandung: Jemmars.

Woolfolk, A.E. and L.M. Nicolich. 1984. Educational Psychology for Teachers. New Jersey: Prentice-Hall, Inc.

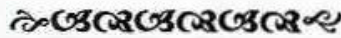

